\author{
Michał Buchowski \\ mbuch@amu.edu.pl \\ Instytut Etnologii i Antropologii Kulturowej \\ Uniwersytet im. Adama Mickiewicza w Poznaniu \\ Uniwersytet Europejski Viadrina we Frankfurcie n. Odrą
}

\title{
ANTROPOLOGIA POLSKA: GENEALOGIE, TRAJEKTORIE I ETYCZNE POWINNOŚCI ${ }^{1}$
}

\author{
Polish Anthropology: Genealogies, \\ Trajectories and Ethical Obligations
}

\begin{abstract}
Streszczenie: Tekst jest autorską interpretacją stanu współczesnej polskiej antropologii. Wychodzi od przedstawienia jej specyficznych korzeni intelektualnych. Choć w głównej mierze była dyscypliną budującą narody, a nie kolonialne imperia (w myśl podziału Halpern i Hammela), to zawsze były w niej obecne tematy pozalokalne i pozaeuropejskie, zaś myślenie prominentnych badaczy było kosmopolityczne. Pomimo izolacji po II wojnie światowej jeszcze w okresie późnego socjalizmu odbudowywała się jako nauka kosmopolityczna, dziś wysoce zróżnicowana i włączona w system „antropologii światowych”. Na tle innych dyscyplin cechują ją nie tylko metody badawcze, lecz kompleksowe, holograficzne podejście do przedmiotu badań. W glosie krytycznej autor postuluje odejście od paradygmatu „kulturalistycznego”, czyli ograniczania interpretacji do sfery inherentnych i autonomicznych związków między symbolami i ideami, i nakłania do tłumaczenia zjawisk przez ujawnianie powiązań tych ostatnich z procesami i relacjami społecznymi. Wskazuje też, jak istotne w czasach rosnących nastrojów ksenofobicznych i rasistowskich są aspekty etyczne uprawiania antropologii i powinności antropologów.
\end{abstract}

Słowa kluczowe: polska antropologia; etnografizm; kosmpolityczność; różnolitość; etyczność.

Abstract: Text presents the author's subjective view on the history and current state of the art of Polish anthropology. It starts with a description of its specific intellectual roots. Although it was not an empire-building enterprise but rather a nation-building one (according to Halpern and Hammel's distinction), global issues have always been studied and addressed, and prominent scholars were cosmopolitan in thinking and doing anthropology. Post-war isolation was overcome already in the period of late socialism and the discipline quickly recovered as a cosmopolitan and diversified intellectual enterprise, a part of "world anthropologies". It works not only with specific

${ }^{1}$ Tekst ten napisałem w trakcie mojego akademickiego rocznego urlopu naukowego (2016-2017), będąc afiliowany jako Overseas Visiting Professor przy Narodowym Muzeum Etnologicznym w Osace, Japonia; moim gospodarzom dziękuję za gościnę i wsparcie. / I have written this text as a Visiting Overseas Professor at National Museum of Ethnology in Osaka, Japan, in the academic year 2016-17. I thank my hosts for their support of my research. 
research methods, but has a complex, holographic attitude to the research subject. In a critical gloss on the Polish "ethno-anthropology" the author claims that the prevailing "culturalist" approach which focuses on an autonomous field of inherent relations between symbols and ideas should be strengthened by studies showing the intricate relationship between culture and social processes and relations. He also emphasises how important ethical issues and anthropologists' ethical obligations are, especially in current times of growing xenophobia and racism.

Keywords: Polish anthropology; ethnographism; cosmopolitism; diversality; ethical obligations.

\section{Uwagi wstępne}

Odpowiedzieć na pytanie o stan polskiej antropologii jest trudno². Poniżej wychodzę z założenia, że w przedsięwzięciu takim uwzględnić trzeba historię na tle przemian kontekstu społecznego, w jakim przychodziło antropolożkom i antropologom działać. Nieodzownym jest też wzięcie pod uwagę trajektorii, po jakich poruszają się antropologie światowe. $W$ tej różnorodności na miejscu jest przypomnienie podstawowych zasad, które definiują dyscy plinę i decydują o reprezentowanym przez związane z nią środowisko etosie. To właśnie podejście badawcze i etos rozstrzygają o tym, czy ktoś jest antropolożką lub antropologiem. Refleksje te z konieczności przedstawiam w kilku zaledwie rysach. Dla zasady, albowiem w ten sposób schlebić można nielicznym, a urazić wielu, nie przytaczam żadnych nazwisk osób żyjących, chyba że się na ich publikacje powołuję.

\section{Genealogie}

Tak jak różnorodne są formy życia ludzi, tak też różne są antropologie funkcjonujące w symbiozie z podłożem społecznym, z którego wyrastają. Nie miejsce tu na wykładanie całego spektrum możliwej genezy. Dyskusji i definicji było co niemiara. W dość ekwilibrystycznym myślowo wywodzie, Claude Lévi-Strauss (1970) sugerował, by w interesującym nas obszarze to etnologia była „królową" nauk. Uważam, że z wielu względów przyjąć należy, że terminem ogólnym, najbardziej poręcznym i obejmującym wszystkie rodzaje praktyki badawczej związanej z nauką o człowieku, jego kulturze i sposobie zorganizowania życia społecznego, jest antropologia. Termin „etnologia”

\footnotetext{
${ }^{2}$ Tekst ten powstał w reakcji na ankietę Polskiego Towarzystwa Ludoznawczego Etnografia - etnologia - antropologia kulturowa dzisiaj. Cele, zakresy i praktyki badawcze oraz wyzwania na przyszłość, którą w 2016 r. rozesłali Katarzyna Majbroda i Wojciech Piasek. Dziękuję im za inspirację. Odpowiedź na postawione przez nich, acz swobodnie przeze mnie potraktowane pytania, tłumaczy i określa styl mojej wypowiedzi.
} 
mniej przekonująco wskazuje na szeroki zakres zainteresowań ludzi parających się kulturowo-społecznymi aspektami życia Człowieka, a sama w sobie nazwa sugeruje raczej skupienie się na grupach etnicznych, etniach czy etnosach, ich właściwościach kulturowych i przestrzennym zróżnicowaniu. Wyklucza też z pola skojarzeń antropologię biologiczną we wszelkich jej wcieleniach. To rzecz jasna kwestia arbitralnych definicji i można się dalej sprzeczać, dzieląc włos na czworo. Pragmatycznym argumentem za stosowaniem antropologii jako terminu rodzajowego przemawia po prostu Realpolitik - antropologia jest najpowszechniej stosowanym terminem już nie tylko w krajach anglosaskich i nie ma sensu tracić sił w jałowych raczej sporach terminologicznych, których toczenie przypominałoby bitwy Don Kichota.

Tradycje antropologii w powyższym i przybliżonym w ostatniej części sensie można dzielić na różne sposoby. Tutaj podążam tropem, który w dużym stopniu definiuje status współczesnej antropologii polskiej. Chodzi o powszechnie znane, lecz jakże trafne, a po raz pierwszy tak nazwane przez Joela Halperna i Eugena A. Hammela (1969), rozróżnienie na antropologie tworzące imperium i antropologie tworzące narody. Rzecz oczywista, kształtowanie się obydwu modeli determinowane było uwarunkowaniami historycznymi i społeczno-politycznymi, zaś samo pojęcie modelu implikuje, że nie wszystkie przy padki w nim sięłatwo mieszczą. Rodzaj antropologii budującej narody stał się dominujący w Europie Środkowo-Wschodniej i od tej chwili nazywał go będę umownie etnologia, co zresztą nie jest żadną nowinką czy idiosynkrazją. Jednocześnie od razu wskazać można studia badaczy pochodzących z regionu, a zajmujących się ludami innymi niż polski lub słowiański. Może najbardziej znamienna, gdyż jednocześnie uwarunkowana politycznie, była w przypadku polskich autorów tradycja studiów prowadzonych na Syberii, zaś nazwiska Wacława Sieroszewskiego, Bronisława Piłsudskiego, Stanisława Poniatowskiego czy Marii Czaplickiej od razu przychodzą ma myśl. Przeto powiedzieć można, że w ogólnym przekroju mieliśmy do czynienia w dziejach polskiej antropologii, w duchu Halperna i Hammela skrojonej klasyfikacji, z etnoantropologia, tradycją, w której - by użyć pomocniczych w tym kontekście terminów niemieckich - Volkskunde i Völkerkunde istniały obok siebie i wzajemnie się uzupełniały. Zresztą wybitny przedstawiciel węgierskiej néprajz, Mihály Sárkány pisał, że „zaskakującą cechą etnografii (etnologii) w Europie Środkowej i Wschodniej jest to, że nigdy nie było tu absolutnego podziału na badania prowadzone w kraju i na odległych terenach" (Sárkány 2002: 562). Na użytek tego artykułu będę więc, jeśli to 
tylko stosowne, posługiwał się terminem etnoantropologii, uwzględniającym symbiozę tradycji kontynentalnej i imperialnej.

Istnienie nurtu „powszechnego”, który przekornie nazwać można ethnologyabroad oraz ogólne zacięcie teoretyczne wielu polskich antropologów - by wspomnieć tylko Ludwika Krzywickiego, Kazimierza Moszyńskiego, Jana Czekanowskiego czy, w nieco późniejszym okresie, Andrzeja Waligórskiego - podpowiada, że wszelkie uogólnienia można zawsze poddać w wątpliwość. Ponadto mapa etniczna kraju i tradycja studiów słowianoznawczych sprzyjały zróżnicowanym zainteresowaniom i rodzajom uprawiania anthropology at home. Przeto do dziś imponują badania Józefa Obrębskiego na Polesiu i w Macedonii, Romana Reinfussa na Podkarpaciu czy studia innych badaczy i badaczek nad kulturami żydowską i innych mniejszości. Niemniej faktem jest, że zdecydowana większość polskich etnoantropologów, zarówno w okresie międzywojennym, jak i powojennym, zajmowała się polskim ludem. Spojrzenia teoretyczne mogły być różne, od fenomenologii, przez historię kultury i durkheimowskie badania wyobrażeń zbiorowych, po coś, co określam jako „etnografizm” etnologii w czasach pierwszych dekad realnego socjalizmu (Buchowski 2012), jednak przedmiot studiów był najczęściej ten sam - społeczności wiejskie i warstwy nieelitarne społeczeństwa żyjącego pod rozbiorami na terenach byłej I Rzeczpospolitej, a potem w obrębie II Rzeczpospolitej i na koniec w Polsce Ludowej. W ten sposób, świadomie lub nie, polska etnologia, podobnie jak i wiele jej kontynentalnych sióstr, przez dziesięciolecia dokładała swoje cegiełki we wznoszeniu gmachu samoświadomego narodu. W okresie socjalizmu szło to w parze z waloryzacją ludu już nie tylko jako nosiciela rdzennych tradycji etnicznych, lecz także wartości społecznie pożądanych w państwie, w którym ów lud pracujący miast i wsi ucieleśniał istotę wartości kulturowych, będących osią narodowej tożsamości i podglebiem postępowych idei awangardy narodu, czyli partii komunistycznej. Jeśli w połowie XIX wieku chodziło o pozyskanie ludu dla idei narodowej, a hasłem było „z szlachtą polską, polski lud”, to w połowie XX wieku, powiedzieć można, zamieniono je w hasło „naród z partią, partia z narodem”, z tym że - jak już się rzekło - szlachta została jako stan zdegradowana i zniesiona, zaś lud, ta autentyczna substancja narodu, miał budować teraźniejszość i świetlaną przyszłość $\mathrm{z}$ nową przewodzącą mu "czerwoną szlachtą" $\mathrm{i}$ to na večne časy a nikdy inak, jak głosiły slogany w komunistycznej Czechosłowacji. 
Niemniej i tego typu dominacja etnologii, w tym czasie przemianowanej na etnografię własnego społeczeństwa (w praktyce jego warstw plebejskich w okresie realnego socjalizmu) nie powstrzymała tradycji prowadzenia badań poza Polską. I tego zagadnienia nie muszę w tym miejscu obszernie rozwijać. W przeszłości Andrzej Waligórski czy Andrzej Zajączkowski robili badania w Afryce, Maria Frankowska w Ameryce Środkowej, zaś Leszek Dzięgiel i Krzysztof Wolski na Bliskim Wschodzie. W latach 70. wyruszały tzw. ekspedycje etnologiczne do Mongolii, Afryki, Indii, Afganistanu i Ameryki Łacińskiej. Nie w tej pozapolskiej i pozaeuropejskiej tematyce tkwi wszelako istota rzeczy. Etnoantropologia jako całość wyzwalała się z etnografizmu, tej mieszanki empiryzmu i pozytywizmu motywowanej romantycznymi mitami na temat ludu, i rozwijała się teoretycznie już od lat 70. Pozwalała na to polityka władz zezwalająca na import z pozoru neutralnych nowinek intelektualnych, która spowodowała nieoczekiwanie, że - przykładowo - niektóre prace Claude’a Lévi-Straussa przełożono na polski prędzej niż na angielski, dzięki czemu do 1970 r. jego cztery ważne książki, Smutek tropików, Totemizm, Antropologia strukturalna i Myśl nieoswojona, czytane były przez ciekawe świata osoby, niestety niekoniecznie przez wszystkich etnografów i wszystkie etnografki. Znamienne, że dzieła te promowały głównie osoby związane z filozofią i socjologią, a nie etnologią, a tłumaczką niektórych z nich była prawniczka Zofia Steinsbergerowa, później współzałożycielka i członkini Komitetu Obrony Robotników. Niemniej przyswajanie strukturalizmu, fenomenologii, strukturalizmu brytyjskiego, semiotyki szkoły z Tartu i dzieł antropologów amerykańskich spowodowało „antropologizację” etnologii. Jej efektem były narodziny tzw. nowej etnologii polskiej, szkoły metodologicznej inspirowanej epistemologią historyczną wpisaną w społeczno-regulacyjną teorię kultury Jerzego Kmity oraz publikowanie szeregu prac stawiających na „dynamizację i poszukiwanie (w tym zapożyczanie) subtelniejszych podstaw teoretycznych dla dotychczasowych i nowych tematów badawczych oraz sposobów ich realizacji” (Szynkiewicz 1992: 24). Jednocześnie rozwijała się coraz bardziej dynamicznie antropologia uprawiana przez grono badaczy wywodzących się z socjologii, którzy wbrew dość powszechnym opiniom nie byli jedynie zaangażowani w odkrywanie formacji myślowej „młodego” Bronisława Malinowskiego czy też rewitalizację jego funkcjonalizmu, lecz także podejmowali wiele innych tematów. Może więc termin etno-socjo-antropologia oddawałby od tej pory sytuację bardziej adekwatnie? Pewnie tak, tym bardziej, że sięgając dalej w historii polskiej antropologii, trudno nie uwzględnić takich klasyków, jak Stefan Czarnowski czy Florian Znaniecki. 
Wspominam o tych procesach także po to, by zasygnalizować, że ożywienie teoretyczne po okresie dominacji etnografizmu miało miejsce na blisko dwie dekady przed przewrotem politycznym 1989 r. Rzecz jasna, środowisko etno-socjo-antropologiczne nie funkcjonowało w próżni i zmiany takie wiązały się z procesami postępującej liberalizacji polityki naukowej oraz w kontekście transformacji całego spektrum nauk humanistycznych i społecznych. Nie powstrzymała tego procesu nawet czasowa stagnacja w okresie stanu wojennego. Utrzymuję tym samym, że diagnoza Adama Kupera, mówiąca o tym, iż „badacze w Europie Wschodniej mieli skłonność do obstawania przy tradycyjnych, nacjonalistycznych tematach związanych z tradycjami chłopskimi, a ich prace zawierały niewiele treści teoretycznych lub były mało przydatne dla celów porównawczych" (Kuper 1996: 192), była nietrafna - przynajmniej w odniesieniu do Polski. Nie wiem, czy ruch wyzwalający dyscyplinę z okowów etnografizmu był rewolucją, lecz z pewnością były to teoretyczne jaskółki, które czyniły wiosnę. Dzięki nim, otwarciu na świat i zmianom zasad funkcjonowania nauki w postkomunistycznej Polsce, etnoantropologia rozwinęła swe skrzydła, zarówno instytucjonalne, jak i teoretyczne.

\section{Teraźniejszości}

Tak jak wszelkie generalizacje były trudne w przeszłości, tak obecnie stały się jeszcze bardziej ryzykowne. Kiedy pisze się historię etnoantropologii polskiej w okresie do I wojny światowej, okresu międzywojennego, czy po II wojnie światowej, jakkolwiek jest ona złożona i bogata, to dominuje w niej kilkanaście, może trochę ponad dwadzieścia nazwisk. I tak, w okresie przedwojennym wystarczy zapoznać się z dziełami kilku kierowników katedr uniwersyteckich, by sensownie wypowiedzieć się w kwestii istniejących orientacji teoretycznych; tego zresztą można się dowiedzieć z opracowań dotyczących historii intelektualnej dyscypliny. W ostatecznym rozrachunku nie chodzi nawet o rosnącą wraz z upływem lat liczbę wchodzących w grę postaci, lecz nade wszystko o to, czy i które osoby odcisnęły na rozwoju dyscypliny jakieś piętno. Jeszcze w latach 80. liczba osób pracujących we wszystkich katedrach i pierwszych instytutach uniwersyteckich przypuszczalnie przekraczała nieznacznie pół setki. Opis tego, co działo się, nie jest nadto skomplikowany. Ponieważ w tych akademickich kręgach etnografizm miał się wciąż dobrze, pojawiające się nowinki rzucają się nam dziś w oczy i nietrudno je odnotować oraz wyeksponować. Obecnie 
sytuacja jest o wiele bardziej złożona i jej charakterystykę zacznijmy od przytoczenia pewnych liczb.

Pod koniec 2016 r. przejrzałem dane dotyczące placówek etnologicznych i antropologicznych dostępne na stronach internetowych. Jak to ze „statystykami” bywa, oddają one rzeczywistość tylko częściowo, czasem są trudne do interpretacji lub mogą prowadzić do mylnych wniosków. Nie każda widniejąca na stronie danej instytucji osoba uprawia faktycznie etnoantropologię, niektóre, będąc na czasowych pobytach $\mathrm{w}$ innych instytucjach, widnieją w dwóch miejscach; nie do końca wiadomo, jak traktować osoby zatrudnione do realizacji ograniczonych przecież czasowo grantów. Niemniej z tego pobieżnego zestawienia wynika, że liczba zatrudnionych pracowniczek i pracowników naukowych tylko w instytutach, katedrach oraz zakładach „etnologii i antropologii kulturowej” wynosiła łącznie 134 - Poznań 26, Warszawa 23, Kraków 16, Cieszyn 15, Łódź 14, Wrocław 14, Toruń 9, Szczecin 9 i Gdańsk 8. W Polskiej Akademii Nauk Ośrodek Antropologii Współczesności w swych placówkach w Warszawie, Poznaniu i Krakowie zatrudniał 18 osób. W Instytutach Socjologii istnieją zakłady mające w swej nazwie antropologię społeczną: Akademia Górniczo-Hutnicza 10 oraz Uniwersytety: Jagielloński 8, Gdański 7, Warszawski 4 i Mari Curie-Skłodowskiej 2. Na Uniwersytecie Warszawskim jest także Zakład Antropologii Kulturowej w Instytucie Filozofii (4 osoby) oraz Katedra Historii Idei i Antropologii Kulturowej w Instytucie Stosowanych Nauk Społecznych (6). Łącznie daje to liczbę blisko dwustu, dokładnie 193, pracowniczek i pracowników nominalnie reprezentujących etnologię i/lub antropologię na uniwersytetach i w akademiach nauk. Do tego dochodzą liczne osoby rozsiane po innych placówkach akademickich i badawczych, np. instytutach PAN, choćby Instytucie Slawistyki czy Sztuki, oraz na różnych wydziałach szkół wyższych. Setki prowadzących badania i publikujących ludzi pracuje w 8 skansenach i 48 muzeach, w których nazwie pojawia się „etnografia”. Polskie Towarzystwo Ludoznawcze ma ok. 700 członków, co nota bene czyni je jednym z najliczniejszych na świecie. Dokonania tego środowiska ludzi identyfikujących się z etnoantropologią publikuje się w trudno policzalnych książkach i kilkunastu specjalistycznych czasopismach.

Czemu ta wyliczanka, skądinąd myślę pożyteczna, ma służyć? Ano temu, aby uzmysłowić, iż dziś zdiagnozowanie najważniejszych trendów rysujących się w obrębie dyscypliny uprawianej przez co najmniej kilkaset osób jest bardzo trudne i konia z rzędem osobie - no i chapeu bas, jak się mawia na salonach - która czyta 
choćby jedną dwudziestą tego, co się w obrębie szeroko rozumianej dyscypliny antropologicznej w Polsce i w odniesieniu do Polski tworzy. To, co przeszło trzy dekady temu o sytuacji w antropologii amerykańskiej pisała Sherry Ortner, w całej rozciągłości - toutes proportions gardées - odnosi się dziś do sytuacji w Polsce.

Nie ma już wspólnego dyskursu, podzielanego zestawu terminów, z którymi zwracają się do siebie uczestnicy praktyki, podzielanego języka, którym my wszyscy, jakkolwiek idiosynkratycznie, mówimy... [Nasza] dziedzina jawi się w postaci strzępków i zagonów, jednostek i małych koterii prowadzących nieprzystające do siebie badania i mówiących głównie do samych siebie... Nie powołujemy już nawzajem naszych nazwisk (Ortner 1984: 126-127).

Dyspersja zainteresowań, podejmowanych tematów i podejść badawczych jest nieunikniona. W takiej sytuacji określenie, jakie paradygmaty dominują w polskiej antropologii, jest skomplikowane, tak jak skomplikowane są tradycje uprawiania tej dyscypliny reprezentowane przez kręgi osób pracujących w instytucjach, w których preferuje się badania na określone tematy, podejścia teoretyczne i rozumienia dyscypliny. Parafrazując Marshalla Sahlinsa, chciałoby się powiedzieć, że różni ludzie, różne antropologie. Jeszcze w połowie lat 90. próbowałem tę sytuację w naszej etno-socjoantropologii opisać w terminach fratrii i klanów (Buchowski 1995), co było zabiegiem i tak upraszczającym rzeczywistość, ale wydaje mi się wciąż sensownym. Dziś tego rodzaju zadanie jest o wiele trudniejsze. Niemniej pozostaje faktem, że w natłoku docierających do nas impulsów w postaci publikacji, wypowiedzi i treści nauczania bezustannie należy czynić starania, mające na celu śledzenie możliwych trendów, by w ogóle orientować się, na jak ruchomych piaskach w tej płynnej ponowoczesności to oczywiście nieodżałowany Zygmunt Bauman - usiłujemy się poruszać.

Lokalność i osobliwość naszej tradycji etnoantropologicznej jest szansą, lecz może też być pułapką. Zawężenie horyzontów do własnego kraju, skupianie uwagi na własnych opłotkach bez porównawczej perspektywy, to praktyka nazwana w studiach innego ty pu "nacjonalizmem metodologicznym”. Punktem odniesienia w rozważaniach są dane pochodzące z narodowych statystyk i innych zamkniętych w granicach państwa źródeł; znaczenie tego terminu poszerzyć można o podobnie ograniczone terytorialne dyskursy publiczne czy też zasoby intelektualne, do których się sięga, a wtedy mówić będziemy o „etnologicznym nacjonalizmie metodologicznym". Łatwo może on stać się - czasem bezwiednie, czasem otwarcie - zalążkiem otwartej gloryfikacji własnych, narodowych tradycji, które ustanawia się przy tym 
dość arbitralnie, esencjalizując pojęcie kultury. To mechanizm znany XIX-wiecznemu ludoznawstwu zainteresowanemu budowaniem narodu, lecz wówczas cele były emancypacyjne, wyzwalające grupy społeczne i etniczne, zaś dziś efekt jest odwrotny. Przykładowo - a nie jest to przypadek wydumany - badawcza fascynacja szopkami krakowskimi prowadzić może do postawy, która postrzega naród jako nienaruszalną całość, dla której elementy uznawane arbitralnie za „obce” stanowią śmiertelne zagrożenie, czy będzie to świętowanie Halloween czy uchodźca, mylony do tego z imigrantem. To tak, jakby ornitolog mylił orła z kaczką, a zootechnik nie odróżniał knura od maciory.

Jak powiedziałem, zakres, rozmach i rodzaj prowadzonych studiów o charakterze antropologicznym jest niezwykle obszerny i jego podsumowanie jest karkołomne. Powiem jedynie o tych badaniach, które osobiście uważam za wyróżniające naszą „narodową” tradycję antropologiczną i zarazem potencjalnie nośne w wymiarze bardziej powszechnym. Pierwszą z nich jest kontynuacja studiów z zakresu teorii antropologicznych. Otwarcie na świat pozwoliło na zwielokrotnienie idących zewsząd inspiracji. Są zapewne osoby, które podważają sens tego rodzaju refleksji, lecz jest ona dla konstytucji każdej dyscypliny niezbędna. Mieszczą się tu między innymi spory o uniwersalizm i partykularyzm kultur, o strukturalizm i postmodernizm, o antropologię scjentystyczną i interpretacyjną, względnie refleksyjną oraz komentujące kolejne „zwroty” w antropologii. Drugą osobliwością polskiej etnoantropologii jest mocna obecność nurtów fenomenologicznego i hermeneutycznego. Fenomenologia sięga czasów Cezarii Baudouin de Courtenay-Ehrenkreutz-Jędrzejewiczowej, reaktywowana została przez Annę Zadrożyńską-Barącz pod koniec lat 60. i kontynuowana jest z powodzeniem do dziś przez grono twórczych postaci. Fenomenologia w dość oryginalny sposób wzmocniona została inspiracjami płynącymi z hermeneutyki, co przyniosło kilka naprawdę intersujących dzieł. Trzecim wątkiem są studia nad postsocjalizmem. Nie chodzi, rzecz jasna, o wszystkie studia, które miały miejsce po 1989 r., lecz takie, które w antropologiczny sposób problematyzowały zagadnienie zachodzących zmian społecznych i kulturowych. Mieściły się tu - na przykład badania klas społecznych i ich kulturowych wyobrażeń, ubóstwa czy płci kulturowej - wszystkie zagadnienia widziane w perspektywie ekspansji neoliberalnego kapitalizmu na obszary zdominowane uprzednio przez reżimy komunistyczne. Dziś za ich kontynuację uznać można analizy przyczyn i mechanizmów reakcji ksenofobicznych, w szczególności agresywnego nacjonalizmu. Listę tę uzupełnić 
trzeba o szereg nowych dziedzin, które stanowią wyraz kosmopolityzmu lokalnej antropologii i świadczą o integracji z nurtami badań prowadzonych w powszechnej skali. Opisać je można, stosując kombinację tematów i podejść. Chodzi więc o wielorakie studia pozapolskie, $w$ tym europejskie, antropologię medyczną, badania płci kulturowej, antropologię polityczną, badania tożsamości, etniczności i migracji, studia LGBT, studia z szeroko pojętej dziedziny STS czy nowocześnie postawionej kwestii dziedzictwa kulturowego. Wszystko to wpisuje się we współczesny stan polskiej antropologii społecznokulturowej.

\section{Glosa krytyczna}

Jakkolwiek zróżnicowana jest sytuacja antropologii społecznokulturowej dziś, to uważam, że jest ona zbyt kulturowa, a za mało społeczna. Nie chodzi rzecz oczywista o to, czy w dostatecznej mierze wykorzystujemy osiągnięcia brytyjskiej antropologii, która jest po prostu jedną z wielu prowincji antropologicznych świata. Zresztą dziś podziały nie przebiegają wzdłuż granic państwowych, nawet jeśli jest nią Kanał La Manche lub ocean. Rzecz w tym, że mówienie o kulturze bez uwzględniania faktu, iż jest ona wy tworem społeczeństwa, odrywa ją od podłoża, z którego wyrasta. Jeśli ktoś o tym podkreślanym w podręcznikach dyscypliny fakcie zapomina, to uprawia jednowymiarową antropologię tropiącą idee, symbole i wyobrażenia tak, jakby to była dziedzina bytów niezależnych od aktorów i relacji między nimi. W ahistorycznym duchu historia kultury danego społeczeństwa przeradza się w historię powiązań treści, znaków i elementów światopoglądu bez uwzględnienia społecznej charakterystyki ich wyrazicieli; kultura jest traktowana jak duch oderwany od ciała. Jego całkiem groźną konsekwencją może być jednostronny „kulturalizm”, przekonanie, że kultura jest czynnikiem determinującym ludzkie działania. Odmiana etnologii z zacięciem społecznym była obecna w polskiej myśli etnologicznej po II wojnie światowej. Przykładem są studia z zakresu historii społecznej autorstwa Józefa Burszty, Bohdana Baranowskiego czy Andrzeja Woźniaka. Także metoda integralna Dobrowolskiego zawierała w sobie postulat badania podłoża historycznego i przeprowadzenia analizy społecznej, lecz zwłaszcza ten ostatni element został rychło zapoznany. Powodów odsunięcia nurtu analizy społecznej w polskiej tradycji antropologicznej na boczny tor jest kilka. Zbyt łacno uznano być może, iż społeczeństwo, zwłaszcza własne społeczeństwo, to przedmiot badań socjologii. Wydaje się także, że wulgarny mark- 
sizm propagowany przez władze odwodził niechętnych reżimowi politycznemu od zajmowania się tematami łączonymi w jakikolwiek sposób z perspektywą klasową. Nawet kategoria ludu przerodziła się ze społecznej w folklorystyczną i stał się on nosicielem wiejsko-narodowych tradycji kulturowych, które należy rekonstruować i pielęgnować. Negowanie etnografizmu także przybrało „kulturalistyczną” postać. W manifeście nowej etnologii znaleźć można otwarte deklaracje, iż uprawiana etnologia nie ma być socjologizująca lub ekonomizująca, jej twórcy postrzegają człowieka jako „twórcę znaczeń", chodzi im o akcentowanie „znaczeniowej strony kultury” oraz skupienie się na kulturze duchowej (Benedyktowicz i in. 1980: 47). Trudno o bardziej otwarte umieszczenie kultury w społecznej próżni. Ponieważ opcja ta imponowała licznym przedstawicielom następnych pokoleń kształconych w Polsce etnologów i etnolożek, przeto nie dziwi jej względna dominacja. Strukturalne powiązania symboli, ich semiotyka, fenomenologia i hermeneutyka wypełniały treść publikacji. Ucieczka od etnografizmu w stronę teorii i metodologii nauki w szkole poznańskiej także przybrała postać analizy idei antropologicznych. W koncepcji J. Kmity sięgnięto po jego epistemologię historyczną, zaś pominięto potencjał tkwiący w społeczno-regulacyjnej teorii kultury, w której pojęcie praktyki społecznej powiązanej z kulturą było jednym z podstawowych; dopiero w studiach nad postsocjalizmem wykorzystano jej możliwości w tym zakresie. Również antropologizujący socjologowie zajmowali się głównie historią i teorią antropologii, a nie analizą społecznie determinowanych ekspresji kulturowych. W latach 90. fascynacja niektórych badaczy i badaczek interpretywizmem Clifforda Geertza, a następnie postmodernizmem $\mathrm{z}$ jego ideami subiektywizmu, literackością i właściwie całkowitym odwróceniem się od krytyki społecznej, również sprzyjała kontynuacji kulturalizmu polskiej antropologii w naszym stuleciu. Kombinacja wszystkich tych czynników zadecydowała, iż do dziś w panoramie polskiej antropologii społeczno-kulturowej ten pierwszy człon jest wciąż za słabo reprezentowany. Wszystko to w czasach, kiedy w cytowanym artykule Ortner podkreślała, że różne antropologie tego okresu spajało pojęcie praktyki.

Rzecz jasna nie o negowanie doniosłości studiów nad „kulturą duchową” chodzi. "Autonomiczne" badanie kultury ma rację bytu i nie w każdej pracy należy kompleksowo odmalowywać powiązania form kulturowych ze stosunkami społecznymi. Jednak powszechność tej praktyki jest tak wielka, że ta podstawowa prawda została poniekąd wyparta ze świadomości większości członków i członkiń naszego polskojęzycznego antropologicznego plemienia. Podnoszę ten argument, aby ten 
fakt uprzytomnić. Przede wszystkim jednak uważam, że uprawianie antropologii we współczesnym świecie do tradycji krytyki społeczno-kulturowej nieuchronnie nawiązuje. Jest to świat globalnych zależności i nierówności, społecznego wykluczenia i dyskryminacji, władzy dyskursów i siły bezwzględnie sprawowanej władzy. Stąd wszelkie prace mieszczące się w tym społecznym nurcie - badania relacji klasy i kultury, studia genderowe, antropologia zaangażowana i radykalna, studia nad przemocą, ksenofobią i nacjonalizmem, badanie migracji, antropologia polityki i prowadzonych polityk zdrowotnych czy energetycznych, studia miejskie, badanie społeczeństwa obywatelskiego lub ruchów alternatywnych, by wymienić niektóre z nich - są godne odnotowania i wsparcia, nie tylko ze względu na dotychczasowy deficyt tego rodzaju analiz, lecz także na ich społeczną doniosłość. Myślę zresztą, że powodów do narzekania w tym względzie jest szczęśliwie coraz mniej. Tym bardziej, że w duchu systemowego myślenia, badając lokalne przejawy związków kultury z klasami społecznymi, uwzględnia się rolę globalnych zależności i procesów.

\section{Differentia specifica}

Wbrew nasuwającej się samej logice narracji, nie zacznę od przybliżenia istoty antropologii jako ogólnej nauki o Człowieku i mądrości, która z niej płynie; o tym w następnej części artykułu. Najpierw odniosę się do kwestii szczegółowych - żywotności we współczesnej antropologii elementów kojarzonych z ludoznawstwem i etnografią, zagadnienia, które wciąż niektórych nurtuje. To punkt wyjścia do określenia metodologicznych, teoretycznych i epistemologicznych zasad postępowania badawczego antropologii. Krokiem następnym będzie opisanie postawy i etosu niezbędnych do tego, by antropologiem lub antropolożką się mienić.

Jeśli ludoznawstwo ma polegać na badaniu ludu rozumianego w XIX-wiecznym sensie, tak jak pisali o nim Antoni Kalina czy Jan Karłowicz, to takiej grupy społecznej w Polsce - włączonej w międzynarodowe migracje od półtora stulecia, funkcjonującej w industrializowanym świecie od równie dawna, a w globalizowanym od ćwierć wieku oraz, w sensie instytucjonalnym, w europejskich strukturach od ponad dekady - po prostu nie ma. Natomiast ludoznawstwo polegające na historycznych studiach nad klasą chłopską oraz tradycjami wiejskimi czy plebejskimi $\mathrm{w}$ zurbanizowanych obszarach jest rodzajem antropologii historycznej w pełni uprawnionym. Zauważmy, że popularne w kręgu nowej etnologii polskiej badanie 
„kultury ty pu ludowego", której przedstawiciele garściami czerpali przecież z archiwów Kolberga i innych kolekcjonerów „starożytności słowiańskich”, było także, skupionym na kulturze symbolicznej, unowocześnionym ludoznawstwem.

Z kolei jeśli etnografię kojarzymy z rzeczonym etnografizmem, to wolałbym, aby była to melodia przeszłości. Zastosowana w niej metoda-cum-teoria, najcelniej opisana już przed laty przez Katarzynę Kaniowską (1984), mimowolnie stała się paradygmatem dominującym w polskiej etnologii (Volkskunde) przez dwie dekady z okładem, który powodował stagnację intelektualną, z jakiej dyscyplina - jak się rzekło - zaczęła się wyrywać w latach 70., a epigoni paradygmatu długo jeszcze trwali w swych akademickich okopach. Sam w sobie pomysł „metody integralnej” Kazimierza Dobrowolskiego nie był chybiony, zwłaszcza że analiza „podłoża historycznego" odgrywała w nim ważną rolę, lecz w praktyce przerodziła się ona w rzeczony etnografizm. Doprowadził on etnologię na manowce deskryptywizmu, którego szczytem konceptualnych możliwości stała się towarzysząca mu „teoria przemian kultury ludowej" dokonujących się w dobie socjalistycznej modernizacji. Historia zredukowana była najczęściej do opisu faktów, a nie procesów społecznych. Jeśli jednak umówimy się, że etnografię traktujemy jako metodę badań empirycznych, której celem jest zebranie materiału przez bezpośredni kontakt z osobami lub grupami, które badamy, to jest to termin kojarzący się jak najbardziej pozytywnie.

Dwa zastrzeżenia są jednak w tym momencie konieczne. Po pierwsze, etnografia jako metoda opierająca się na obserwacji uczestniczącej i wywiadzie już dawno nie jest jedynym sposobem pozyskiwania materiałów w antropologii. Zbiera się je $\mathrm{w}$ różnych miejscach i na różne sposoby - w archiwach, w znalezionych listach, w wypowiedziach publicznych, na forach internetowych i w innych miejscach ekspresji w wirtualnym świecie. Dwie dekady temu George E. Marcus (1998) pokusił się o wyszczególnienie wielorakich sposobów zbierania danych w coraz bardziej mobilnym, kłączowym czy ryzomatycznym i erratycznym świecie. Wraz ze zmianami świata ewoluują także metody badań, które pozwolą „podążać za łańcuchami, ścieżkami, wątkami, skrzyżowaniami i splotami miejsc, w których etnografka lub etnograf ustanawia formy dosłownej, fizycznej obecności..." (1998: 90). W ten sposób można śledzić ludzi, przedmioty, metafory, wątki, historii, alegorie i biografie (Marcus 1998: 90-94). Po drugie, etnografia jako metoda już dawno nie jest wyłączną własnością antropologii. Stała się powszechna w naukach społecznych, nawet jeśli strażnicy „prawdziwej etnografii” upierać się będą, że powierzchowne jej stosowanie 
„to nie to". Zgadza się, lecz rozstrzygając tę sprawę, zostajemy jedynie z wpojony mi zasadami, intuicją, smakiem i - być może w ostatecznej instancji - środowiskowym konsensusem odnoszącym się do tego, co jest, a co nie jest dobrą etnografią. Niemniej z paragrafu tego płynie konkluzja, że metoda badań empirycznych w formie „dosłownej, fizycznej obecności” sama w sobie nie jest wystarczająca, aby zdefiniować antropologię. Etnografia, to nasze hołubione dziecko, zostało nam uprowadzone i nie jest w stanie wypełnić roli swoistego experimentum crucis. Zresztą definiowanie dyscypliny wyłącznie przez metodę jest raczej wątpliwym zabiegiem z teoriopoznawczego punktu widzenia.

Inna rzecz, że długotrwała obecność w terenie i uczestniczenie w życiu ludzi badanych, naszych partnerek lub partnerów w terenie, jak to się teraz zwykło już określać, pozostaje jedną z wyróżniających charakterystyk dyscypliny, którą wymienia się jednym tchem z zestawem innych cech. Najważniejszą z nich jest chyba uniwersalizm przymiotów człowieczeństwa, ujawniany przez pryzmat relatywizmu, czyli odkrywanie jedności w różnorodności. Inaczej mówiąc, chodzi o bezustanne pokazywanie wyjątkowości sposobu życia danej grupy lub wchodzących ze sobą w interakcje podmiotów indywidualnych bądź zbiorowych, zorganizowania społecznego i kulturowego, a przez to, jakby na przekór i paradoksalnie, odkrywanie strukturalnych zbieżności i jedności. Nie jest to zatem żaden relatywizm moralny, lecz relatywizm poznania, zaś antropologia nie wystrzega się przed mówieniem tego, co w zachowaniu ludzi lub zorganizowaniu życia społeczeństwa może być złe. Także racjonalizm ludzkich podmiotów nie jest pojęciem z etnocentrycznego arsenału, w myśl którego każdy powinien myśleć tak, jak chciałby tego Kartezjusz lub Gottlob Frege, lecz wszyscy mamy zdolność logicznego myślenia w ramach obowiązujących reguł kulturowych; w ten sposób racjonalizm relatywizujemy. Znaczy to także, iż zagłębiając się w misterium życia ludzi w innych od naszego kontekstach, nie uznajemy za miarodajne etnocentrycznych wyznaczników standardów życia, czy są to normy dotyczące „jedynie słusznego” modelu rodziny, czy czyniące z dochodu na głowę mieszkańca obiektywny miernik dobrostanu i szczęścia. Nie dajemy więc wiary ani apostołom uniwersalnej moralności, ani misjonarzom, spłaszczonego do jednego wymiaru widzenia, życia społecznego. Usilnie staramy się przedstawić obraz holograficzny. To napięcie między uniwersalizmem i partykularyzmem okazuje się czynnikiem konstytuującym oraz motorem napędowym trwania i transformacji antropologii. 
Cecha stanowiąca o osobliwości dyscypliny, owa oscylacja między uniwersalizmem i partykularyzmem, kryje w sobie następną: antropologia jest z natury swej przedsięwzięciem porównawczym. Skoro mówimy o ludzkiej jedności i zróżnicowaniu, to siłą rzeczy w tle każdej konstatacji kryje się zabieg porównania z innymi sytuacjami, kontekstami, społeczeństwami, stylami życia czy kulturami. Rzeczowe porównanie sposobów istnienia różnych grup i pokazanie zarówno ich odrębności, jak i podobieństw jest możliwe właśnie dzięki empirycznemu zgłębianiu codziennych praktyk metodami etnograficznymi. Prowadzi to $\mathrm{z}$ kolei do pokazania, w jaki sposób poszczególne systemy są zintegrowane, jakie są powiązania między różnymi elementami kultury, aspektami życia materialnego, społecznego i duchowego, by użyć tej standardowej ongiś klasyfikacji reifikującej kulturę. Choć jest wiele nauk zajmujących się człowiekiem w jego wymiarze społeczno-kulturowym - psychologia, socjologia, nauki polityczne, kulturoznawstwo, historia i inne - to holizm spojrzenia (i użyte właśnie pokrewne terminy integracji, relacji, powiązań, holografii) stanowi istotę antropologii. Holizm rozumie się przy tym nie w duchu funkcjonalizmu, jako zintegrowaną całość kulturową, lecz, jakkolwiek brzmi to paradoksalnie, skomplikowaną, pełną napięć i sprzeczności praktykę powiązanych ze sobą na różne sposoby aktorów społecznych.

W świetle powyższych uwag, antropologia jawi się jako nauka, która porównawczo i za pomocą metod etnograficznych nakierowanych na badanie życia ludzi w różnych kontekstach ukazuje jedność człowieka jako istoty racjonalnej, uwikłanej w życie społeczne, w którym w dynamicznej relacji uwarunkowań historyczno-strukturalnych i działających w nich sprawczych jednostek, tworzy się bezustannie zmieniające się formy kultury, stanowiące dla uczestników wydarzeń ramy odniesienia dla interpretacji sytuacji i podejmowania działań. Sprawczość ludzi rozumiana jest w duchu Pierre’a Bourdieu. W momencie ich podjęcia działania jednostek stają się częścią praktyki społecznej, którą staramy się konceptualnie ogarniać przez dopatrywanie się pewnych regularności oraz cech istotnych strukturalnie. Niemniej praktyka społeczna istnieje tylko dzięki ludziom, którzy w niej uczestniczą, a ich działania przyczyniają się do jej trwania i bezustannego przetwarzania. Podobna właściwość przysługuje towarzyszącym działaniom przekonaniom. Nie chodzi przy tym bynajmniej o fetyszyzowanie czy uprzywilejowywanie sprawczości aktorów i stawianie ich indywidualnych poczynań ponad systemem kultury, lecz o wskazanie, że system i podmiotowość istnieją tylko razem. 


\section{Kosmopolityzm}

Porównawczy charakter przedsięwzięcia antropologicznego oznacza, że jest ono na wskroś kosmopolityczne, rzecz jasna nie w sensie, w jakim używa się go w dyskursach politycznych. I ten moment pozwala mi ponownie wrócić do sytuacji we współczesnej etnoantropologii polskiej. Symbioza studiów powszechnych i krajowych zawsze $\mathrm{w}$ jakiś sposób sprzyjała realizacji kosmopolitycznego ideału, lecz to nie obszar zainteresowań jest w tej kwestii decydujący. Można badać i opisywać odległe ludy i w ten sposób przyczyniać się do poszerzania horyzontów wiedzy o różnorodności kulturowej świata, o wielobarwnym „kuwejckim bazarze” różniącym się od „klubu angielskich dżentelmenów", jak to ujął Clifford Geertz (1986). Wszak nie o bycie "handlarzami egzotyki” chodzi, o czym przekonywał dawno temu Roger Keesing (1989). To zadanie zostawmy podróżnikom, reportażystom i tym kulturoznawcom, którym tanie linie lotnicze umożliwiają nagle zachłystywanie się różnorodnością świata i powierzchowną refleksję o odległych ludach, praktykowanie „sztuki zadziwienia" inspirowanej kontaktem z odmiennością kulturową. Można przecież badać zamorskie wspólnoty i pozostawać wyrobnikiem etnografizmu, co bynajmniej nie przybliża takiego mozołu do kosmopolityzmu. W antropologicznym kosmopolityzmie istotą jest podejście do przedmiotu studiów.

Łatwo zauważyć, że znaczna część pokolenia antropologów do II wojny światowej kształciła się na wielu uniwersytetach europejskich. Zurich, St. Petersburg, Berlin, Lipsk, Paryż czy Londyn to były adresy, pod którymi można było spotkać młodego Czekanowskiego, Kalinę, Malinowskiego, Czaplicką, Znanieckiego, Czarnowskiego, Józefa Obrębskiego i wielu innych. Byli przy okazji poliglotami, pracowali w różnych państwach - Czekanowski, na przykład, w pruskim, rosyjskim i na koniec w polskim, zarówno przed-i powojennym, a w czasie wojny spędził jakiś czas na Morawach. Siłą rzeczy zaznajamiali się z tym, co się w światowej antropologii działo. Po II wojnie tego rodzaju krążenie ludzi i idei zostało przerwane. Chyba nie do końca zdajemy sobie sprawę, jak izolacja w czasach reżimu komunistycznego przyczyniła się do „zaściankizacji” etnologii polskiej i utrwalenia się etnografizmu. Dopiero wspomniane powyżej, rozpoczęte jeszcze w późnym socjalizmie, otwarcie na idee z zewnątrz, a dziś praktycznie nieograniczona możliwość czerpania z zasobu teorii pochodzących $\mathrm{z}$ różnych tradycji intelektualnych, stworzyło warunki do kosmopolityzacji rodzimej antropologii. Ten rodzaj podejścia, otwartość na idee decyduje o tym, czy uprawiana nauka jest antropologią, której przecież - jak ob- 
staję - nie definiuje sama metoda i przedmiot badań, lecz problematyzacja tematu, implikująca wpisany w konstytucję dyscypliny kosmopolityzm. Nie wynika z tego oczywiście, że koniecznie trzeba kończyć zagraniczne uniwersytety, by taką postawę reprezentować. Niemniej cyrkulacja ludzi i idei, wieloraka edukacja, wyjazdy na stypendia, udział w międzynarodowym życiu naukowym oraz zatrudnianie absolwentek i absolwentów spoza własnej uczelni lub kraju, a więc wszystko to, co przeczy "chowowi wsobnemu”, sprzyja takiemu twórczemu krzyżowaniu idei.

Czynnikiem takim jest też coraz więcej „hybrydowych” sylwetek oraz osób $\mathrm{z}$ angielska zwanych halfies. Mam więc na myśli postacie intensywnie funkcjonujące w międzynarodowym krwiobiegu intelektualnym, których miejscem pracy są obecnie polskie instytucje, choć nie zawsze tylko polskie. Oprócz nich są to antropolożki i antropolodzy, których znaczna część karier przebiegała lub nadal przebiega poza Polską, a jednocześnie kontaktu z krajem nie tracą lub z Polską antropologią się utożsamiają. Wielu pracuje tu, lecz doktoraty robiło poza granicami kraju. Są też tacy, którzy wywodzą się z Polski, polskimi problemami się nadal zajmują, lecz ich kariery przebiegają za granicą. Znaczna część ich twórczości publikowana jest $\mathrm{w}$ językach obcych, szczególnie po angielsku, niekiedy praktycznie tylko w tym języku. Mamy też w Polsce badaczki i badaczy, którzy legitymują się paszportami innych państw, lecz tutaj pracują. Wreszcie jest też liczne grono antropologów i antropolożek, którzy Polską się zajmują, lecz do polskiej tradycji antropologicznej ich się raczej nie zalicza, gdyż ich kariera toczy się od początku do końca za granicą (pewne refleksje na ten temat można znaleźć w setnym numerze czasopisma „Lud”). To praktyczny wymiar hybrydyzacji i kosmopolityzacji.

Kosmopolityczności nie należy też rozumieć jako bezkrytycznego otwarcia na nowinki ze świata, jednostronnego importu idei. Dziś to już nikomu - no, może prawie nikomu - nie imponuje. Rzecz w tym, aby nasza antropologia stała się częścią world anthropologies (proszę zwrócić uwagę na liczbę mnogą), platformy różnych antropologii, która przeciwstawiając się ukształtowanej historycznie hegemonii niektórych tradycji - wynikłej z nierówności ekonomicznych, zależności kolonialnych i dominacji językowych - walczy z zastanymi hierarchiami wiedzy, obnaża mechanizmy formowania centrów i peryferii w systemie wytwarzania wiedzy oraz ujawnia zasady kreowania instytucji cerberów dyscypliny, przypisujących sobie prawo do stanowienia o tym , co jest dobrą antropologią, a co nie. Idea „antropologii światowych" ma pomóc w promowaniu przepływu wiedzy antropologicznej 
w różnych kierunkach i na różnych poziomach. Nie chodzi bynajmniej o przewroty pałacowe, by nagle tworzone na tzw. prowincji idee uczynić centralnymi i odwrócić hierarchie, ale o uzyskanie efektu polifoniczności i „różnolizmu” (diversality) (Ribeiro 2014: 489). W takim modelu jest też rzecz jasna miejsce dla "naszej” antropologii, która, podobnie jak i wiele innych $\mathrm{w}$ regionie, jest w jakiejś mierze połączeniem etnologii i antropologii, Volkskunde i Völkerkunde, i korzysta przy tym z inspiracji dyscyplin pokrewnych. Wymaga to otwarcia i aktywnej receptywności wszystkich wchodzących w grę stron. Wynika ona nie tylko z chęci przyswajania iluminujących koncepcji i szukania analogii służących poszukiwaniom i interpretacjom. Stoi za nią także imperatyw etyczny. „Doświadczenie moralne wiąże się z transformacją samych siebie przez formę wiedzy nam nieznanej" (Butler 2000: b.s.). Judith Butler chce nam powiedzieć, że nie można być ani etycznym, ani krytycznym, jeśli nie chce się przekroczyć własnych paradygmatów myślenia. Aktywne wychodzenie poza własne utarte pojęcia jest nie tylko wyzwaniem intelektualnym, ale i moralnym obowiązkiem wszystkich intelektualistów i intelektualistek, a może przede wszystkim nas mieniących się antropolożkami i antropologami.

\section{Etyczność}

Pewne podstawy dyscypliny bądź rodzaju refleksji pozostają niewzruszone. Antropologia, z greckiego anthropos (człowiek) i logia (badanie, nauka), wprost definiuje przedmiot naszych zainteresowań. Jest nim Człowiek. Staramy się zrozumieć ludzi. Jeśli pojmujemy antropologię szeroko i uwzględniamy ewolucję biologiczną, to sięgamy do pradziejów, a nawet uwzględniamy w tym obrazie historię życia i zachowania Naczelnych. Od swych narodzin w XIX wieku, w czasach rozkwitu kolonializmu, triumfalnego pochodu „cywilizacji białego człowieka” i niekwestionowanego europocentrycznego myślenia, antropologia obstawała przy prawdzie o jedności gatunku ludzkiego. To fakt, że ówcześni adwokaci ewolucjonizmu tworzyli hierarchie społeczeństw, instytucji społecznych i sposobów myślenia; układali je na drabinie postępu, lecz wiedzieli, że mają do czynienia z ludźmi, którzy są nie tylko biologicznie podobni, ale charakteryzują się zdolnością do racjonalnego myślenia, posiadają Kulturę oraz organizują życie w grupach. Stąd klasyczne rozumienie antropologii jako badającej człowieka w jego odmiennych kontekstach środowiskowych - jednego Człowieka w jego różnorodności biologicznej, społecznej i kulturowej. To się nie zmieniło i tak 
antropologię w wielu jej postaciach należy rozumieć. Antropologia jest więc, jak pisze Michael Herzfeld (2004), podsumowując rozważania wiodących badaczek i badaczy na przełomie XX i XXI wieku, terenem zmagań i sporów między teorią i praktyką, podejściami naukowymi i humanistycznymi, dyscypliną, która rzuca światło na aspekty życia, których inne specjalności nie są w stanie dostrzec. Ale przede wszystkim jest nie tylko teoretycznym, lecz także etycznym zobowiązaniem, które pozwala i nakazuje zarazem bezwarunkowo krytykować wszystkie inne odmiany nietolerancji.

Poglądy przeciwstawiające się tym fundamentalnym założeniom o jedności i równości wszystkich ludzi antropologią nie są i lokują osoby je głoszące poza dyscypliną. Gdzie i jak daleko od niej, to już zależy od stopnia odstępstwa od tego udokumentowanego naukowo stanu rzeczy i charakteru ideologii sterującej taką dyskryminującą interpretacją różnorodności ludzi. Wszyscy, którzy przyczyniają się do upowszechniania praktyk wykluczających bądź hierarchizujących ludzi, stawiających im bariery ze względu na rasę, narodowość, kulturę, religię, płeć i wiele innych czynników, przeczą etosowi antropologii i przez brać antropologiczną ich postawy powinny być wyjaśniane, uświadamiane, krytykowane, a ich dyskryminujące i uwłaczające godności ludzkiej konsekwencje negliżowane, a jak trzeba, bezpardonowo potępiane.

A zatem pryncypia antropologii zostały ukształtowane dawno temu. Franz Boas, a nie hrabia Joseph Arthur de Gobineau jest naszym ojcem duchowym. Jeżeli przejawy rasizmu, ksenofobii, nacjonalizmu, homofobii, demagogii i wszelkich form dyskryminacji nie wywołują odruchu sprzeciwu u kogoś, kto się nawet tematami antropologicznymi zajmuje, to dla mnie antropologiem lub antropolożką nie jest. Antropologia to nie tylko zawód, to także postawa moralna. Jak pisze klasyk współczesnej socjologii, „dobre nauki społeczne są zawsze moralne... Próżnia moralna tworzy poznawczo trywialne dzieła... Sterylność wielu prac socjologicznych wynika z ich infantylizmu moralnego... w szczególności, redukcjonizm jako narzędzie poznawcze jest efektem moralnej bojaźliwości lub tchórzostwa" (Bellah, Tipton 2006: 400; podkreślenia moje). Kierując się takimi fundamentalnymi przesłankami i uprawiając kosmopolityczną antropologię, możemy z otwartą przyłbicą stawić czoła wyzwaniom, które niesie nam życie i historia. Przed takim stoimy również w tej chwili, kiedy sprzeczne z naszymi ideałami ideologie w rodzaju rasizmu przystrojonego w szaty kultury i nacjonalizmu, zaprawionego ideologią obrony Europy, polskości i tradycji oraz podanego w przyprawie bezpieczeństwa narodowego powracają jak upiorny 
bumerang. Brak aktywnego stawiania im czoła jest niczym innym, jak wyrazem rzeczonego infantylizmu, bojaźliwości i tchórzostwa, a przy okazji z pewnością nie przyniesie poznawczo wartościowych dzieł. Myślę, że jako środowisko zdajemy egzamin z etyki i antropologii całkiem nieźle. $Z$ małymi przecież wyjątkami, które bardzo bolą, a przy okazji świadczą o braku zrozumienia tego, co się dookoła nas dzieje lub o zwykłym oportunizmie. Na Nadzwyczajnym Zjeździe Antropologów 23 listopada 2016 r. w Poznaniu, obywającym się pod hasłem „Antropologia przeciw dyskryminacji”, pokazaliśmy, że jesteśmy gotowi bronić idei Człowieka, która stanowi fundament antropologii, jej punkt wyjścia i dojścia.

\section{Bibliografia}

Bellah, R., Tipton, R. F. (red.). (2006). The Robert Bellah Reader, Durham: Duke University Press.

Benedyktowicz, Z., Robotycki, Cz., Stomma, L., Tomicki, R., Wasilewski, J.(1980). Antropologia kultury w Polsce - dziedzictwo, pojęcia, inspiracje. Materialy do stownika. Cz. I, Polska Sztuka Ludowa, 34 (1), 47-60.

Buchowski, M. (2012). Etnologia polska. Historie i powinowactwa, Poznań: Wydawnictwo Nauka i Innowacje.

Butler, J. (2000). What is critique? An essay of Foucault's virtue. Pozyskano $\mathrm{z}$ http://eipcp.net/ transversal/0806/butler/\#_ftn3.

Geertz, C. (1986). The uses of diversity. Michigan Quarterly Review, 25, 105-123.

Halpern, J., Hammel E.A. (1969). Observations on the Intellectual History of Ethnology and other Social Sciences in Yugoslavia. Comparative Study in Society and History, 11 (1), 17-26.

Herzfeld, M. (2004). Antropologia: praktykowanie teorii w kulturze i społeczeństwie (przeł. M.M. Piechaczek). Kraków: Wydawnictwo Uniwersytetu Jagiellońskiego.

Kaniowska, K. (1984). Tradycja metodologiczna powojennej etnografii polskiej. Lud, 48, 51-69.

Keesing, R.M. (1989). Exotic readings of cultural texts. Current Anthropology, 30 (4), 459-479.

Kuper, A. (1996). Anthropology and Anthropologists: The Modern British School, London: Routledge. Marcus, G.E. (1998). Ethnography through Thick and Thin, Princeton: Princeton University Press. Ortner, S. (1984). Theory in Anthropology in the Sixties. Comparative Studies in Society and History, 26, 126-166.

Ribeiro, G.L. (2014). World Anthropologies: Anthropological Cosmopolitanism and Cosmpolitics. Annual Review of Anthropology, 43, 483-498. 
Sárkány, M. (2002), Cultural and Social Anthropology in Central and Eastern Europe. W: M. Kaase, V. Sparschuh, A. Wenninger (red.). Three Social Science Disciplines in Central and Eastern Europe. Handbook on Economics, Political Science and Sociology (1989-2001), (ss. 558-566). Berlin-Budapest: Social Science Information Centre(IZ) / Collegium Budapest.

Szynkiewicz, S. (1992). Po co nam antropologia? Etnografia Polska, 36 (1), 21-24. 
